УДК 37.013.42

DOI: https://doi.org/10.35619/iiu.v0i9.126

Павелків Катерина кандидат педагогічних наук, доцент, доцент кафедри іноземних мов Рівненського державного гуманітарного університету, м. Рівне, Україна ORCID: 0000-0002-9112-2542 e-mail: pavelkiv.k@gmail.com

\title{
ІНШОМОВНА КОМУНІКАТИВНА КОМПЕТЕНТНІСТЬ МАЙБУТНІХ ФАХІВЦІВ СОЦІАЛЬНОЇ СФЕРИ: СТРУКТУРА ТА 3MICT
}

\begin{abstract}
Анотація. У статті обгрунтовано необхідність іншомовної комунікативної компетентності майбутніх фахівців соціальної сфери. Здійснено аналіз проблеми формування іншомовної компетентності фахівців різного профілю в різноманітних аспектах: теорія, методологія i методика іншомовної підготовки фахівців. Висвітлено авторське опрацювання реалізації завдань діяльності закладу вищої освіти (у площині Закону України «Про вищу освіту») в іншомовній підготовці студентів. Акцентовано увагу на особливості структурування іншомовної комунікативної компетентності майбутніх фахівців соціальної сфери на підставі аналізу наукових джерел, що представляють методологію, теорію і методику формування означеної компетентності, особливості ії розвитку у процесі навчання у закладі вищої освіти, специфіку структурування іншомовної комунікативної компетентності як науково-педагогічного об'єкта. Схарактеризовано підходи (компетенційний та функціональний) до структурування іншомовної комунікативної компетентності майбутніх фахівців соціальної сфери з урахуванням методології, теорії і методики формування означеної компетентності: компетенційний (розглядає різні компетенції в складі іншомовної комунікативної компетентності), функціональний (за якого кожен компонент несе на собі різне смислове навантаження, виходячи з процесів, які його забезпечують). Визначено орієнтовну структуру іншомовної комунікативної компетентності майбутніх фахівців соціальної сфери у поєднанні чотирьох складників, як-то: мотиваційноаксіологічний (мотиваційні чинники вивчення іноземних мов як важливої цінності для майбутньої професійної діяльності в соціальній сфері), когнітивний (сукупність знань 3 іноземної мови майбутніх фахівців соціальної сфери), діяльнісноповедінковий (як процес навчання, засвоєння, відтворення знань 3 іноземної мови і як способи поведінки студентів в навчальній та квазіпрофесійній комунікативній діяльності іноземною мовою), рефлексивний (здатність студентів до адекватної самооцінки досягнутого рівня сформованості іншомовної комунікативної компетентності та інших само-процесів).
\end{abstract}

Ключові слова: іншомовна комунікативна компетентність, фахівці соціальної сфери, компетенції, структура.

Постановка проблеми. Забезпечення оптимальних умов формування професійних компетенцій фахівців будь-якого профілю нині тісно пов'язується зі знанням ними іноземних мов та вмінням послуговуватися іноземною мовою у ситуаціях, прямо пов'язаних 3 професійною діяльністю, чи опосередковано визначених нею. У зв'язку з цим та відповідно до нової редакції Закону України «Про вищу освіту» (2017), державна політика у галузі вищої освіти 
грунтується на принципі «міжнародної інтеграції та інтеграції системи вищої освіти України у Свропейський простір вищої освіти» (Міністерство освіти і науки України), що, своєю чергою, вимагає від випускника сучасного ЗВО знання однієї з європейських мов, передовсім, англійської як домінуючої в більшості країн Європи. Крім того, означений нормативний акт найвищого рівня задекларував, що «з метою створення умов для міжнародної академічної мобільності заклад вищої освіти має право прийняти рішення про викладання однієї чи кількох дисциплін англійською та/або іншими іноземними мовами, забезпечивши при цьому знання здобувачами вищої освіти відповідної дисципліни державною мовою» (Міністерство освіти і науки України).

Аналіз останніх досліджень 3 проблеми. Проблема формування іншомовної компетентності фахівців різного профілю досить активно нині досліджується педагогічною наукою в різних аспектах: теорія, методологія і методика іншомовної підготовки фахівців (Т. Борова (2013), М. Кенел (1983), С. Козак (2001), О. Нечипорук (2014), Н. Микитенко (2011), О. Павленко (2005), Ю. Рибінська (2013), І. Секрет (2010), Д. Хаймс (1979) та ін.); формування іншомовної комунікативної компетентності студентів (Г. Малиновська (2002), М. Прадівлянний (2006), А. Петрова (2009), Н. Сура (2005) та ін.); структура іншомовної компетентності майбутніх фахівців та їі формування і процесі навчання у ЗВО (Н. Бідюк (2010), В. Галкіна (2014), О. Тинкалюк (2008), Т. Чернюк (2017) та ін.). Проте компонентна структура іншомовної комунікативної компетентності майбутніх фахівців соціальної сфери ще досить рідко досліджується вченими i потребує наукового обгрунтування 3 огляду на специфіку майбутньої професійної діяльності студентів у соціальній галузі.

У зв'язку з цим метою статті $€$ обгрунтування структури іншомовної комунікативної компетентності майбутніх фахівців та змісту кожного 3 компонентів.

Виклад основного матеріалу дослідження. Законом України «Про вищу освіту» (2014) визначено основні завдання закладів вищої освіти в Україні, що, на нашу думку, прямо пов'язані 3 іншомовною підготовкою фахівців різноманітних спеціальностей. Цей зв'язок ми представили в таблиці 1 [авторське опрацювання].

Таблиця 1

Реалізація завдань діяльності закладу вищої освіти (відповідно до Закону України «Про вищу освіту») в іншомовній підготовці студентів

\begin{tabular}{|c|c|}
\hline $\begin{array}{l}\text { Завдання закладу вищої освіти, } \\
\text { визначені Законом Украӥни «Про } \\
\text { вищу освіту» }\end{array}$ & $\begin{array}{l}\text { Реалізація иього завдання у процесі іншомовної } \\
\text { комунікативної підготовки студентів }\end{array}$ \\
\hline $\begin{array}{l}\text { Провадження на високому рівні } \\
\text { освітньої діяльності, яка забезпечує } \\
\text { здобуття вищої освіти відповідного } \\
\text { ступеня } \quad \text { за } \\
\text { спеціальностями }\end{array}$ & $\begin{array}{l}\text { Реалізація завдань професійної підготовки } \\
\text { фахівців вимагає нині високого і достатнього } \\
\text { рівня володіння іноземними мовами студентами } \\
\text { й викладачами як рівноправними суб’єктами } \\
\text { освітнього процесу у ЗВО }\end{array}$ \\
\hline
\end{tabular}




\begin{tabular}{|c|c|}
\hline $\begin{array}{l}\text { Провадження наукової діяльності } \\
\text { шляхом проведення наукових } \\
\text { досліджень і забезпечення творчої } \\
\text { діяльності учасників освітнього } \\
\text { процесу, підготовки наукових } \\
\text { кадрів вищої кваліфікації і } \\
\begin{array}{l}\text { використання } \\
\text { результатів в освітньому процесі }\end{array}\end{array}$ & $\begin{array}{l}\text { Реалізація цього завдання вимагає: } \\
\text { 1) належного знання іноземних мов студентами } \\
\text { з метою здійснення ними наукових досліджень } \\
\text { із залученням досвіду та дослідницьких практик } \\
\text { зарубіжних науковців; 2) підготовки наукових } \\
\text { кадрів вищої кваліфікації зі знанням іноземних } \\
\text { мов на рівні В2 чи вищому, з метою } \\
\text { забезпечення викладання іноземною мовою як } \\
\text { для студентів-іноземців, так і для українських } \\
\text { студентів у ЗВО }\end{array}$ \\
\hline $\begin{array}{l}\text { Участь у забезпеченні суспільного } \\
\text { та економічного розвитку держави } \\
\text { через формування людського } \\
\text { капіталу }\end{array}$ & $\begin{array}{l}\text { Розвиток людського капіталу передбачає } \\
\text { сформованість у майбутніх фахівців сукупності } \\
\text { професійних знань, умінь, навичок на рівні } \\
\text { вимог ринку праці, орієнтованого на } \\
\text { формування комунікативних компетенцій, що } \\
\begin{array}{l}\text { передбачає развинену } \\
\text { комунікативну компетентність }\end{array}\end{array}$ \\
\hline 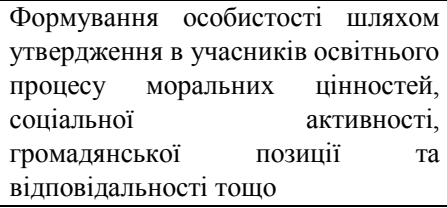 & $\begin{array}{l}\text { Означене завдання вищої освіти реалізується в } \\
\text { аксіологічній компоненті іншомовної } \\
\text { комунікативної компетентності майбутніх } \\
\text { фахівців, у здатності студентів до професійної } \\
\text { соціалізації не лише в рідномовному, але й } \\
\text { іншомовному соціокультурному середовищі }\end{array}$ \\
\hline $\begin{array}{l}\text { Створення необхідних } \text { умов для } \\
\text { реалізації учасниками } \\
\text { процесу їхніх здібностей і талантів }\end{array}$ & $\begin{array}{l}\text { Виконання цього завдання потребує системної } \\
\text { іншомовної підготовки студентів різних } \\
\text { напрямів підготовки, що дозволить їм у процесі } \\
\text { навчання реалізувати свої здібності й знання у } \\
\text { різних освітніх і наукових програмах обміну, } \\
\text { мобільності, міжнародної співпраці }\end{array}$ \\
\hline $\begin{array}{l}\text { Поширення знань серед населення, } \\
\text { підвищення } \quad \text { освітнього } \\
\text { культурного рівня громадян }\end{array}$ & $\begin{array}{l}\text { Розвинена іншомовна компетентність студентів } \\
\text { визначає зростання } \\
\text { загальнокультурного, освітнього і наукового } \\
\text { рівня } 3 \text { метою поширення своїх знань у } \\
\text { професійному та соціальному середовищі }\end{array}$ \\
\hline $\begin{array}{l}\text { Налагодження } r \text { міжнародних } \\
\text { зв'язків; та провадження } \\
\text { міжнародної діяльності в галузі } \\
\text { освіти, науки, спорту, мистецтва і } \\
\text { культури }\end{array}$ & 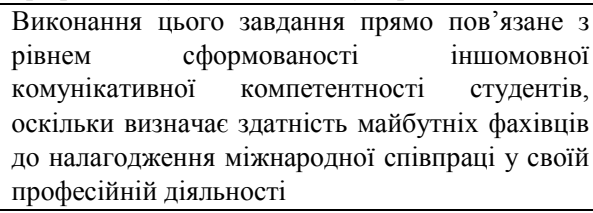 \\
\hline $\begin{array}{lc}\text { Вивчення попиту на окремі } \\
\text { спеціальності } \\
\text { сприяння } \\
\begin{array}{l}\text { випускників } \\
\text { працевлаштуванню праці та }\end{array}\end{array}$ & $\begin{array}{l}\text { Це завдання передбачає } \\
\text { достатнього рівня іншомовної комунікативної } \\
\text { компетентності випускника } 3 B 03 \text { метою } \\
\text { зростання своїх шансів на ринку праці залежно } \\
\text { від обраної професійної галузі }\end{array}$ \\
\hline
\end{tabular}

Результатом іншомовної підготовки студента у процесі навчання у ЗВО є сформована у нього на тому чи іншому рівні іншомовна комунікативна компетентність. Як складне динамічне утворення, іншомовна комунікативна компетентність повинна мати чітко окреслену (з урахуванням майбутнього професійного фаху та змісту професійної підготовки) структуру, яка б відображала різні аспекти означеної компетентності, що розвиваються у 
процесі професійної підготовки. Педагогічна наука накопичила чимало методологічних, теоретичних, методичних підходів до структурування іншомовної компетентності майбутніх фахівців, виходячи 3 їх майбутньої професійної діяльності, змісту професійної підготовки, особистісної мотивації до вивчення іноземних мов, рівня розвиненості психічних процесів (пам'яті, мислення, уяви, уявленні тощо) та ін.

Структура іншомовної комунікативної компетентності концептуально пов'язана зі структурою комунікативної компетентності загалом; остання входить до числа базових життєвих компетенцій особистості, визначених європейськими документами про освіту (Hutmacher, 1997). Найчастіше структура комунікативної компетентності представляється науковцями у єдності лінгвістичного, соціолінгвістичного і прагматичного компонентів; почасти лінгвістична компетенція замінюється мовною, а прагматична мовленнєвою. Ян Ван Ейк виділяє в структурі іншомовної комунікативної компетентності лінгвістичну (словниковий запас і граматика), соціокультурну (обізнаність зі специфікою культурних універсалій носіїв мови), соціолінгвістичну (здатність використовувати мовний ресурс залежно від мовної ситуації), стратегічну (здатність використовувати невербальну чи паралінгвістичну комунікацію при нестачі звичайної), дискурсивну (вміння інтерпретувати інформацію 3 метою створення зв'язних текстів), соціальну (здатність до взаємодії 3 іншими учасниками комунікативного процесу) компетенції (Van, Ek, Waystage, 1990). Є. Абдрузякова обгрунтувала таку структуру іншомовної комунікативної компетентності: мовний (лінгвістичний), соціокультурний, рефлексивний компоненти (2010). А. Микитишин, аналізуючи структуру іншомовної комунікативної компетентності майбутніх програмістів, виділила у ній фактично ті само компоненти - мовний, дискурсивний, соціолінгвістичний, стратегічний, соціальний; проте дослідниця додала до традиційної структури ще суто педагогічні складники - професійно-діяльнісний, психофізіологічний та навчальний (2016). Л. Бахман та А. Плеймер у цій комунікативній компетентності визначають лише три компоненти - мовний, стратегічний i психофізіологічний (1982), Г. Архіпова - п’ять (лінгвістичний, тематичний, соціокультурний, компенсаторний, навчальний) (2006, с.12-13).

Вважаємо важливим для нашого дослідження виокремлення в структурі іншомовної комунікативної компетентності саме компенсаторного (здатність домагатися взаєморозуміння у процесі оволодіння іноземною мовою) та тематичного (володіння екстралінгвістичною інформацією) складників, оскільки для фахівців соціальної сфери ці компоненти іншомовної компетентності мають суттєве професійне значення.

Більш близькими до нашого розуміння структури іншомовної комунікативної компетентності, на нашу думку, $\epsilon$ дослідження, що використовують не компетенційний (різні компетенції в складі іншомовної комунікативної компетентності), а власне функціональний підхід (за якого кожен компонент несе на собі різне смислове навантаження, виходячи 3 процесів, які його забезпечують). Так, у дослідженні В. Галкіної (2014) іншомовна комунікативна компетентність складається 3 мотиваційноцільового, когнітивного, операційного та рефлексивного компонентів; дослідження Т. Власюк (2012) репрезентує такі основні компоненти іншомовної комунікативної компетентності фахівців: гностичний, 
комунікативний, емоційний; Г. Чередніченко (2017) представляє структуру означеної компетентності в поєднанні мотиваційно-ціннісного, когнітивнодіяльнісного та емоційно-вольового компонентів; Н. Завіниченко пропонує поєднувати в структурі іншомовної комунікативної компетентності майбутніх фахівців гностичний, комунікативний та емоційний компоненти (2003, с.47).

Виходячи $з$ аналізу наукових джерел та власного авторського науковопедагогічного досвіду, ми окреслюємо структуру іншомовної комунікативної компетентності майбутніх фахівців соціальної сфери в єдності таких компонентів:

1. Мотиваційно-аксіологічного, в межах якого можливо буде обгрунтувати основні мотиваційні чинники, що спонукають студентів до вивчення іноземних мов, виходячи $з$ їх майбутньої професійної діяльності в соціальній сфері. До цього компонента ми також вносимо аксіологічний складник, враховуючи непересічну цінність спілкування в професійній діяльності фахівців соціальної сфери.

2. Когнітивного, який визначає сукупність знань 3 іноземної мови майбутніх фахівців соціальної сфери, що представлені професійним вокабуляром, знаннями граматики, орфографії, стилістики іноземної мови в межах, необхідних для ii використання в професійній сфері.

3. Діяльнісно-поведінкового, який відображає дві сторони процесу формування іншомовної комунікативної компетентності майбутніх фахівців соціальної сфери: 1) діяльнісну як процес навчання, засвоєння, відтворення знань 3 іноземної мови у вигляді мовленнєвих та комунікативних умінь i навичок; 2) поведінкову - як способи поведінки студентів в навчальній та квазіпрофесійній комунікативній діяльності іноземною мовою.

4. Рефлексивного, що вміщує здатність студентів до адекватної самооцінки досягнутого рівня сформованості іншомовної комунікативної компетентності та інших само-процесів - самоосвіти, самопізнання, самовдосконалення у процесі вивчення іноземної мови.

Висновки і перспективи подальших розвідок. Отже, нами з'ясовано особливості структурування іншомовної комунікативної компетентності майбутніх фахівців соціальної сфери на підставі аналізу наукових джерел, що представляють методологію, теорію i методику формування означеної компетентності, особливості іiі розвитку у процесі навчання у ЗВО, специфіку структурування іншомовної комунікативної компетентності як науковопедагогічного об'єкта. Виокремлено, що у процесі обгрунтування структури іншомовної комунікативної компетентності майбутніх фахівців науковці дотримуються двох підходів - компетенційного (що розглядає різні компетенції в складі іншомовної комунікативної компетентності), та функціонального (за якого кожен компонент несе на собі різне смислове навантаження, виходячи 3 процесів, які його забезпечують). Визначено орієнтовну структуру іншомовної комунікативної компетентності майбутніх фахівців соціальної сфери у поєднанні таких складників: мотиваційноаксіологічного, когнітивного, діяльнісно-поведінкового та рефлексивного.

Перспектива подальших досліджень пов'язується нами з обгрунтуванням змісту кожного зі складників іншомовної комунікативної компетентності майбутніх фахівців соціальної сфери та розробки діагностичного інструментарію для проведення констатувального етапу експериментальної перевірки стану сформованості означеної компетентності. 


\section{СПИСОК ВИКОРИСТАНОЇ ЛІТЕРАТУРИ:}

Міністерство освіти і науки України, (2014). Закон України «Про вищу освіту». Режим доступу: [https://zakon.help/law/1556-VII/edition01.01.2019/].

Борова, Т. (2013). Формування іншомовної компетентності в майбутніх економістів як чинник підвищення якості їхньої професійної підготовки. Педагогіка формування творчої особистості у вищій $і$ загальноосвітній школах. 28. с. 448-455.

Canal, M. (1983). From Communicative Competence to Communicative Language Pedagogy. Richards J. and Schmidt R., (eds.) Language and Communication. London: Longman. P. 2-27.

Козак, С. (2001). Формування іномовної комунікативної компетениії майбутніх фахівців морського флоту. Кандидат педагогічних наук. Південноукраїнський національний педагогічний університет імені К. Д. Ушинського.

Нечипорук, О. (2014). Іншомовна компетентність як передумова професійного розвитку педагога. Педагогічний пошук. 2. с.16-18.

Микитенко, Н. (2011). Теоретичні основи формування іншомовної професійної компетентності майбутніх фахівиів природничих спеціальностей. Тернопіль : ТНПУ. 383 с.

Павленко, О. (2005). Формування комунікативної компетениії фахівців митної служби в системі неперервної професійної освіти. Доктор педагогічних наук. Луганський національний університет імені Тараса Шевченка.

Рибінська, Ю. (2013). Методичні основи формування іншомовної комунікативної компетентності майбутніх філологів засобами креативного перекладу. Київ : Астон. 299 с.

Секрет, I. (2010). Іншомовна професійна компетентність: проблема визначення. Збірник наукових праць Бердянського державного педагогічного університету (Педагогічні науки). 2. с. 312.

Hymes, D. (1979). On Communicative Competence. C. J. Brumfit and K. Jonson (eds.). The Communicative Approach to Language Teaching. London. P. 5-27

Малиновська, Г. (2002) Особливості формування іншомовної комунікативної компетенції майбутнього економіста в процесі його професійної підготовки. Педагогіка і психологія професійної освіти. Науково-методичний журнал. №5. c. $108-117$.

Прадівлянний, М. (2006). Формування професійно спрямованої іншомовної компетентності фахівців технічних та економічних спеціальностей засобами сучасних інформаційних технологій : Кандидат педагогічних наук. Вінницький національний технічний університет.

Петрова, А. (2009). Формування іншомовної компетентності майбутніх менеджерів зовнішньоекономічної діяльності в прочесі фахової підготовки. Кандидат педагогічних наук. Вінницький національний технічний університет.

Сура, Н. (2005). Навчання студентів університету професійно орієнтованого спілкування іноземною мовою. Кандидат педагогічних наук. Луганський національний педагогічний університет імені Тараса Шевченка

Бідюк Н. М. Комунікативна компетентність майбутнього вчителя-філолога зміст і структура. Інформаційно-комунікаційні технології в сучасній освіті: досвід, проблеми, перспективи : зб. наук. праць третьої Міжнародної науково-практичної конференціï. Львів. с. 158-160. Режим доступу ubgd.lviv.ua/konferenc/kon.../Bidjuk.pdf.

Галкіна, В. (2014). Зміст і структура іншомовної професійної компетентності майбутніх магістрів військового управління. Вісник Національного університету оброни Украӥни. - 4(41). с. 24-29. 
Тинкалюк, О. (2008). Сутність і структура іншомовної комунікативної компетенції студентів немовних спеціальностей вищих навчальних закладів. Вісник Львівського університету. Серія педагогічна. Вип. 24. с.53-63.

Чернюк, Т. Сутність і структура іншомовної комунікативної компетентності фахівця 3 фізичної культури і спорту. Витоки педагогічної майстерності. Вип.19. c.358-363.

Hutmacher, W. (1997). Key Competencies for Europe. Report of the Symposium. Berne, Switzerland, 27-30 March, 1996. Council for Cultural Cooperation (CDCC). A Secondary Education for Europe Strasburg.

Van, Ek, Waystage J. (1990). Council of Europe. Conseil de L'Europe. Available at: http://www.mon.gov.ru/pro/pnpo.

Абдуразякова, Е. (2010). Иноязычная коммуникативная компетенция как одна из составляющих личностной и профессиональной характеристик современного специалиста. Режим доступу: [http://www.avkrasn.ru/article-996.html.

Микитишин, А (2016). Структурні компоненти професійної іншомовної комунікативної компетентності майбутніх програмістів. Наукові записки Тернопільського національного педагогічного університету ім. В.Гнатюка. №3. c.142-147.

Bachman, L., Plamer, A. (1982). The Construct Validation of Some Components of Communicative Proficiency. TESOL Quarterly. Vol. 16. \#3. P. 449-465.

Архипова, Г. (2006). Формирование иноязычной компетентности будущего специалиста (медищинского профиля). Кандидат педагогических наук. ГОУ ВПО «Читинский государственный университет».

Власюк, Т. (2012). Іншомовна комунікативна компетентність майбутнього вчителя початкової школи як теоретична проблема. Вісник психологї̈ $i$ педагогіки: збірник матеріалів Міжкафедрального методологічного семінару «Сучасні освітні стратегії формування професійної компетентності майбутніх учителів початкової школи» (22 листопада, 2012 р., м. Київ). Випуск 10. Київ. Режим доступу: [http://www.psyh.kiev.ua/].

Чередніченко, Г. (2017). Сутність і структура іншомовної професійнокомунікативної компетентності майбутніх інженерів-технологів харчової промисловості. Міжнародний філологічний часопис (Науковий вісник НУБіП Украӥни. Серія Філологічні науки). 272. с. 151-159.

Завіниченко, Н. (2003). Особливості розвитку комунікативної компетентності майбутнього практичного психолога системи освіти. Кандидат психологічних наук. Київ. АПН України. Інститут психології ім. Г. С. Костюка.

\section{REFERENCES:}

Ministerstvo osvity i nauky Ukrainy, (2014). Zakon Ukrainy «Pro vyshchu osvitu» [Law of Ukraine "On Higher Education"]. Rezhym dostupu: [https://zakon.help/law/1556-VII/edition01.01.2019/]. [in Ukrainian].

Borova, T. (2013). Formuvannia inshomovnoi kompetentnosti v maibutnikh ekonomistiv yak chynnyk pidvyshchennia yakosti yikhnoi profesiinoi pidhotovky. [Foreign Language Competence Formation of Future Economists as a Mean of Their Professional Training Quality Improvement]. Pedahohika formuvannia tvorchoi osobystosti u vyshchii i zahalnoosvitnii shkolakh. 28. s. 448-455. [in Ukrainian].

Canal, M. (1983). From Communicative Competence to Communicative Language Pedagogy. Richards J. and Schmidt R., (eds.) Language and Communication. London: Longman. P. 2-27.

Kozak, S. (2001). Formuvannia inshomovnoi komunikatyvnoi kompetentsii maibutnikh fakhivtsiv morskoho flotu. [Foreign Language Communicative Competence Formation of Future Specialists of the Marine]. Kandydat pedahohichnykh nauk. 
Pivdennoukrainskyi natsionalnyi pedahohichnyi universytet imeni K. D. Ushynskoho. [in Ukrainian].

Nechyporuk, O. (2014). Inshomovna kompetentnist yak peredumova profesiinoho rozvytku pedahoha. [Foreign Language Competence as a Precondition of Teacher's Professional Development]. Pedahohichnyi poshuk. 2. s.16-18. [in Ukrainian].

Mykytenko, N. (2011). Teoretychni osnovy formuvannia inshomovnoi profesiinoi kompetentnosti maibutnikh fakhivtsiv pryrodnychykh spetsialnostei. [Theoretical Foundations of Foreign Language Professional Competence Formation of Future Natural Sciences Specialists]. Ternopil : TNPU. 383 s. [in Ukrainian].

Pavlenko, O. (2005). Formuvannia komunikatyvnoi kompetentsii fakhivtsiv mytnoi sluzhby v systemi neperervnoi profesiinoi osvity. [Communicative Competence Formation of Customs Specialists in the System of Continuous Professional Education]. Doktor pedahohichnykh nauk. Luhanskyi natsionalnyi universytet imeni Tarasa Shevchenka. [in Ukrainian].

Rybinska, Yu. (2013). Metodychni osnovy formuvannia inshomovnoi komunikatyvnoi kompetentnosti maibutnikh filolohiv zasobamy kreatyvnoho perekladu. [Methodical Foundations of Foreign Language Communicative Competence Formation of Future Philologists by Means of Creative Translation]. Kyiv : Aston. 299 s. [in Ukrainian].

Sekret, I. (2010). Inshomovna profesiina kompetentnist: problema vyznachennia. [Foreign Language Professional Competence: the Problem of Definition]. Zbirnyk naukovykh prats Berdianskoho derzhavnoho pedahohichnoho universytetu (Pedahohichni nauky). 2. s. 312. [in Ukrainian].

Hymes, D. (1979). On Communicative Competence. C. J. Brumfit and K. Jonson (eds.). The Communicative Approach to Language Teaching. London. P. 5-27 [in English]

Malynovska, H. (2002) Osoblyvosti formuvannia inshomovnoi komunikatyvnoi kompetentsii maibutnoho ekonomista $\mathrm{v}$ protsesi yoho profesiinoi pidhotovky. [The Peculiarities of Foreign Language Communicative Competence Formation of Future Economist in the Process of His Professional Training]. Pedahohika $i$ psykholohiia profesiinoi osvity. Naukovo-metodychnyi zhurnal. No 5. s. 108-117. [in Ukrainian].

Pradivliannyi, M. (2006) Formuvannia profesiino spriamovanoi inshomovnoi kompetentnosti fakhivtsiv tekhnichnykh ta ekonomichnykh spetsialnostei zasobamy suchasnykh informatsiinykh tekhnolohii. [The Formation of Professionally Oriented Foreign Language Competence of Technical and Economical Professions Specialists by Means of Modern Information Technology]. Kandydat pedahohichnykh nauk. Vinnytskyi natsionalnyi tekhnichnyi universytet. [in Ukrainian].

Petrova, A. (2009). Formuvannia inshomovnoi kompetentnosti maibutnikh menedzheriv zovnishnoekonomichnoi diialnosti v protsesi fakhovoi pidhotovky. [Foreign Language Competence Formation of Future Managers of Foreign Economic Activity in the Process of Professional Training]. Kandydat pedahohichnykh nauk. Vinnytskyi natsionalnyi tekhnichnyi universytet. [in Ukrainian]

Sura, N. (2005). Navchannya studentiv universy’tetu profesijno oriyentovanogo spilkuvannya inozemnoyu movoyu. [Teaching of University Sstudents of Professionally Oriented Communication in Foreign Language]. Kandydat pedahohichnykh nauk. Luhanskyi natsionalnyi pedahohichnyi universytet imeni Tarasa Shevchenka. [in Ukrainian].

Bidiuk N. M. Komunikatyvna kompetentnist maibutnoho vchytelia-filoloha: zmist i struktupa. [Communicative Competence of Future Philology Teacher: the Content and Structure]. Infopmatsiino-komunikatsiini tekhnolohii v suchasnii osviti: dosvid, ppoblemy, pepspektyvy : $z$. nauk. ppats tpetoi Mizhnapodnoi naukovo-ppaktychnoi konfepentsii. 
Lviv. s. 158-160. Pezhym dostupu : ubgd.lviv.ua/konferenc/kon.../Bidjuk.pdf. [in Ukrainian].

Halkina, V. (2014). Zmist i struktura inshomovnoi profesiinoi kompetentnosti maibutnikh mahistriv viiskovoho upravlinnia. [The Content and Structure of Foreign Language Professional Competence of Future Master's Degree Students of Military Department]. Visnyk Natsionalnoho universytetu obrony Ukrainy. 4(41). s. 24-29. [in Ukrainian].

Tynkaliuk, O. (2008). Sutnist i struktura inshomovnoi komunikatyvnoi kompetentsii studentiv nemovnykh spetsialnostei vyshchykh navchalnykh zakladiv. [The Essence and Structure of Foreign Language Communicative Competence of Students of Nonlinguistic Specialties in Higher Educational Establishments]. Visnyk Lvivskoho universytetu. Seriia pedahohichna. Vyp. 24. s.53-63. [in Ukrainian].

Cherniuk, T. Sutnist i struktura inshomovnoi komunikatyvnoi kompetentnosti fakhivtsia z fizychnoi kultury i sportu. [The Essence and Structure of Foreign Language Communicative Competence of Physical Education and Sport students]. Vytoky pedahohichnoi maisternosti. Vyp.19. s.358-363. [in Ukrainian].

Hutmacher, W. (1997). Key Competencies for Europe. Report of the Symposium. Berne, Switzerland, 27-30 March, 1996. Council for Cultural Cooperation (CDCC). A Secondary Education for Europe Strasburg.[in English]

Van, Ek, Waystage J. (1990). Council of Europe. Conseil de L'Europe. Available at: http://www.mon.gov.ru/pro/pnpo.

Abdurazyakova. E. (2010) Inoyazychnaya kommunikativnaya kompetentsiya kak odna iz sostavlyayushchikh lichnostnoy i professionalnoy kharakteristik sovremennogo spetsialista. [Foreign Language Communicative Competence as One of the Components of Personal and Professional Characteristics of Modern Specialist]. Rezhym dostupu: [http://www.avkrasn.ru/article-996.html. [in Russian].

Mykytyshyn, A. (2016). Strukturni komponenty profesiinoi inshomovnoi komunikatyvnoi kompetentnosti maibutnikh prohramistiv. [Structural Components of Professional Foreign Language Communicative Competence of Future Programmers]. Naukovi zapysky Ternopilskoho natsionalnoho pedahohichnoho universytetu im. V.Hnatiuka. No3. s.142-147. [in Ukrainian].

Bachman, L., Plamer, A. (1982). The Construct Validation of Some Components of Communicative Proficiency. TESOL Quarterly. Vol. 16. No 3. P. 449-465. [in Ukrainian].

Arkhipova. G. (2006) Formirovaniye inoyazychnoy kompetentnosti budushchego spetsialista (meditsinskogo profilya). Kandidat pedagogicheskikh nauk. GOU VPO "Chitinskiy gosudarstvennyy universitet". [in Russian].

Vlasiuk, T. (2012). Inshomovna komunikatyvna kompetentnist maibutnoho vchytelia pochatkovoi shkoly yak teoretychna problema. [Foreign Language Communicative Competence of Future Primary School Teacher as a Theoretical Problem]. Visnyk psykholohii $i$ pedahohiky: zbirnyk materialiv Mizhkafedralnoho metodolohichnoho seminaru "Suchasni osvitni stratehii formuvannia profesiinoi kompetentnosti maibutnikh uchyteliv pochatkovoi shkoly" (22 lystopada, 2012 r., m. Kyiv). Vypusk 10. Kyiv. Rezhym dostupu: [http://www.psyh.kiev.ua/]. [in Ukrainian].

Cherednichenko, H. (2017) Sutnist i struktura inshomovnoi profesiinokomunikatyvnoi kompetentnosti maibutnikh inzheneriv-tekhnolohiv kharchovoi promyslovosti. [The Essence and Structure of Foreign Language Professional and Communicative Competence of Future Engineers and Technologists in Food Industry]. Mizhnarodnyi filolohichnyi chasopys (Naukovyi visnyk NUBiP Ukrainy. Seriia Filolohichni nauky). 272. s. 151-159. [in Ukrainian].

Zavinychenko, N. (2003). Osoblyvosti rozvytku komunikatyvnoi kompetentnosti maibutnoho praktychnoho psykholoha v systemy osvity. [Developmental Peculiarities of Future Practical Psychologist's Communicative Competence in Educational System]. 
Kandydat psykholohichnykh nauk. Kyiv. APN Ukrainy. Instytut psykholohii im. H. S. Kostiuka. [in Ukrainian].

FOREING LANGUAGE COMMUNICATIVE COMPETENCE OF FUTURE SOCIAL SPHERE SPECIALISTS: THE STRUCTURE AND CONTENT

\author{
Kateryna Pavelkiv \\ Candidate of Pedagogical Sciences, Associate Professor, \\ Associate Professor at the Department of English Language \\ Rivne State University of the Humanities \\ Rivne, Ukraine \\ ORCID: 0000-0002-9112-2542 \\ e-mail:pavelkiv.k@gmail.com
}

\begin{abstract}
The necessity of foreign language communicative competence of future social sphere specialists is grounded in the article. The analysis of the problem of foreign language competence formation of different types specialists in various aspects has been carried out: theory, methodology and methods of foreign language specialists' training. It is shown the author's working out of tasks implementation of higher educational establishment activity (according to Law of Ukraine "On Higher Education") at foreign language training of students. The attention is focused on the peculiarities of foreign language communicative competence of future social sphere specialists structuring on the basis of scientific resources analysis, which present methodology, theory and methods of mentioned above competence formation, the specialties of its development during educational process at higher educational establishment, structuring specificity of foreign language competence as a scientific and pedagogical object. It is characterized the approaches (competent and functional) to foreign language competence of future social sphere specialists structuring considering methodology, theory and methods of mentioned above competence formation: competent (considers different competencies as a part of foreign language communicative competence), functional (according to which every component has different meaning, based on processes that provide it). The approximate structure of foreign language communicative competence of future social sphere specialists in combination of four components is defined, such as: motivational and axiological (motivational factors of foreign language learning as an important value for future professional activity in social sphere), cognitive (a set of foreign language knowledge of future social sphere specialists), activity and behavioral (as a process of training, learning, creation of knowledge and as means of students' behavior in educational and quasi-professional communicative activities in foreign language), reflexive (students' ability to an adequate self-esteem of achieved level of foreign language communicative competence formation and other self-processes).
\end{abstract}

Key words: foreign language communicative competence, social sphere specialists, competences, structure.

Стаття надійшла до редакиї 22.04.2019 p. 